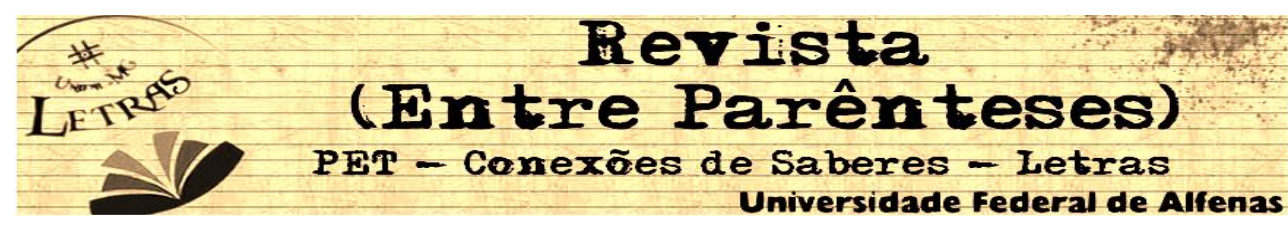

\title{
APRENDENDO MAIS QUE GRAMÁTICA: COMO OS FUTUROS PROFESSORES DE ESPANHOL PERCEBEM OS ELEMENTOS PRAGMÁTICO-DISCURSIVOS EM ORAÇÕES CONDICIONAIS EM ESPANHOL
}

\author{
Maria de los Angeles de Castro Ballesteros ${ }^{1}$ \\ PG - Universidade de São Paulo \\ (delo.ballesteros@usp.br )
}

\begin{abstract}
Resumo: Os aspectos pragmático-discursivos que subjazem às estruturas gramaticais constituem um problema no processo de ensino-aprendizagem de línguas estrangeiras devido às formas como as línguas codificam o conhecimento em suas construções. Nesse sentido, pretende-se investigar como os licenciandos de um curso de Letras/Espanhol percebem os elementos pragmático-discursivos das Orações Condicionais em espanhol. Esta pesquisa, partindo de um estudo contrastivo das orações condicionais em espanhol e português, relacionou e categorizou as diferenças entre suas estruturas e as possibilidades modo-temporais que agregam informações pragmáticas ao discurso, nas duas línguas. Utilizando questionários e testes elaborados para possibilitar o estudo do processamento e do processo de produção, com base na pesquisa de Vygotsky (2001), buscou-se evidenciar a percepção que os licenciandos têm acerca das estruturas condicionais em espanhol. A análise das respostas avaliou o "rascunho mental" e a percepção do "subtexto" nos enunciados dos sujeitos de pesquisa, identificando estratégias discursivas conscientes ou não em contraste com as utilizadas para a construção de sentidos na língua espanhola. Ao final, foi possível reconhecer as dificuldades de apreensão das estruturas condicionais pelos sujeitos, evidenciando, que para eles os aspectos pragmáticos e os efeitos de sentido, decorrentes das combinações modo-temporais das construções condicionais em Espanhol, são, eventualmente quase imperceptíveis.
\end{abstract}

Palavras-chave: E/LE; Pragmática; Orações condicionais.

Resumen: Los aspectos pragmático-discursivos que subyacen las estructuras gramaticales constituyen un problema en el proceso de enseñanza-aprendizaje de lenguas extranjeras debido a las formas como las lenguas codifican el conocimiento sus construcciones. En este sentido, se pretende investigar como los estudiantes de un curso de Letras/Español perciben los elementos pragmático-discursivos de las Oraciones Condicionales en español. Esta investigación, tuvo como objetivo relacionar y categorizar las diferencias existentes entre las estructuras y las posibilidades modo-temporales que agregan informaciones pragmáticas al discurso, en las dos lenguas, por medio de estudios contrastivos de las oraciones condicionales en español y portugués. Se buscó evidenciar la percepción que los licenciandos tienen acerca de las estructuras condicionales en español aplicando cuestionarios y testes elaborados de forma a posibilitar un análisis del procesamiento y del proceso de producción, con base en la pesquisa de Vygotsky (2001) sobre el pensamiento y su relación con el lenguaje. El análisis de las respuestas evaluó el «borrador mental» y la percepción del «subtexto» en los enunciados de los sujetos, identificando estrategias discursivas conscientes o no en contraste con las utilizadas para la construcción de sentidos en español. Al final, fue posible reconocer las dificultades de aprehensión de las estructuras condicionales por parte de los sujetos, una vez que quedó evidente que, para ellos, los aspectos pragmáticos y los efectos de sentido, resultantes de combinaciones modo-temporales de las oraciones condicionales en Español, eventualmente, son casi imperceptibles.

Palabras-clave: E/LE; Pragmática; Oraciones condicionales.

\footnotetext{
${ }^{1}$ Mestranda do programa de pós-graduação em Língua Espanhola e Literaturas Espanhola e HispanoAmericana, da Faculdade de Filosofia, Letras e Ciências Humanas, da USP. Técnica em Assuntos Educacionais da Pró-Reitoria de Extensão da UNIFAL-MG.

$1 \frac{\text { Revista (Entre Parênteses) }}{1}$
}




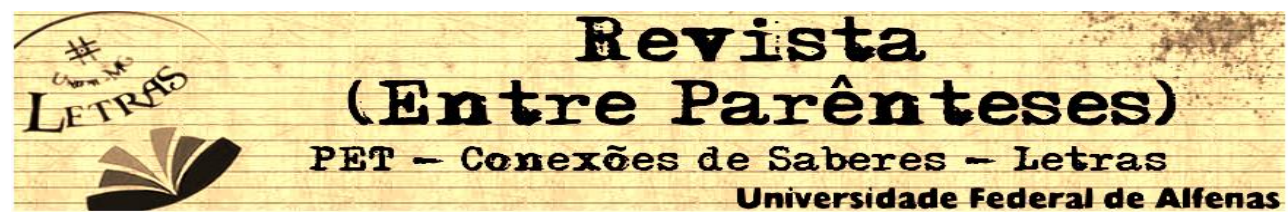

\section{Introdução}

No centro das discussões e estudos relacionados a fatores concorrentes para a baixa qualidade da Educação, encontra-se a formação inicial do professor. Mizukami (2004) relata estudos de Shulman $(1986,1987,1996,2004)$ que apontam para uma lacuna nas pesquisas quanto à forma como um conteúdo específico é apreendido pelo aluno graças a uma formulação equivocada de professores. Especificamente no caso dos cursos de Letras que propõem a habilitação em Língua Estrangeira (LE), Paiva (2005) alerta para a necessidade de atenção aos conteúdos específicos para a formação em LE, quando em cursos de dupla habilitação: "Conteúdos de formação do professor de língua estrangeira são, geralmente, ignorados, e é raro o curso que oferece atividades curriculares que estimulem reflexões sobre a aquisição, ensino e aprendizagem de língua estrangeira" (PAIVA, 2005, p. 360)

Com base nessas observações, é possível afirmar que o espaço reservado aos conteúdos específicos da LE parece ser insuficiente para o desenvolvimento da competência comunicativa do futuro professor. No caso do ensino/aprendizagem de Espanhol como Língua Estrangeira (E-LE), além dos problemas resultantes das condições inadequadas para formação docente em LE - carga horária insuficiente para o estudo da língua e da literatura, turmas grandes, etc - a proximidade tipológica entre Espanhol e Português é um fator a mais que demanda atenção por parte do curso, pois, como nos explicam Kulikowski e González (1999, p. 15)

La tan mentada cercanía facilita presuposiciones que después no se confirman, pero que son muy resistentes (todos entienden todo), en síntesis, crea o permite una transparencia engañosa que se presta a innumerables equívocos y empobrece la lectura, la comprensión, la interpretación y la producción de los aprendientes.

Apesar da mesma origem - o Latim, entre essas duas línguas há um universo cultural distinto e distante que não pode ser apreendido quando o foco do aprendizado está nas estruturas gramaticais e morfossintáticas. Trata-se de marcas culturais, reflexo do modo de ser, pensar e agir de um povo estrangeiro que, normalmente, ficam sob o

Revista (Entre Parênteses)

Volume 1, Número 5, 2016 - ISSN 2238-4502 


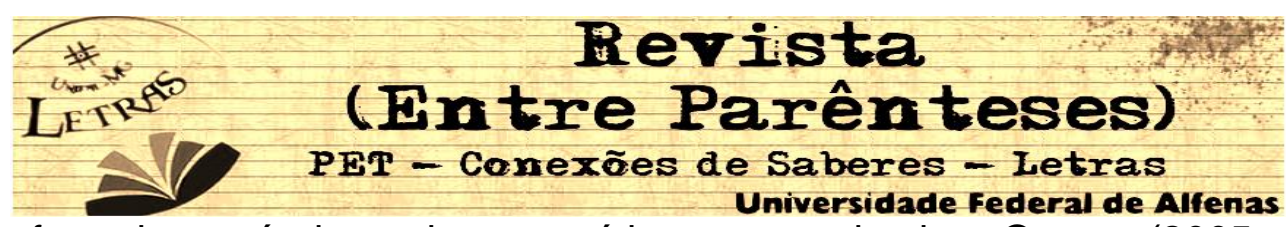

texto $^{2}$ e fora do currículo e das gramáticas, como lembra Ortega (2005, p. 515). Também Escandell Vidal (2009, p. 98) faz um alerta sobre essa crença:

todo sería mucho más fácil para todos nosotros si las lenguas solo difirieran entre sí en lo que se refiere a la gramática. [...]. Sin embargo, sabemos que las cosas no son tan sencillas: las lenguas difieren entre sí no sólo en lo gramatical, sino también en todos aquellos aspectos de su uso que están determinados por factores no estrictamente gramaticales, es decir, en los aspectos pragmáticos. Por tanto, comunicarse eficazmente en una lengua no consiste sólo en conocer y manejar bien su gramática, sino que implica también hacerse con un dominio adecuado de un complejo conjunto de conocimientos de naturaleza extragramatical.

Os componentes extragramaticais de que nos fala Escandell Vidal constituem elementos pragmático-discursivos que subjazem as construções morfossintáticas de uma língua e que codificam valores socioculturais do falante. Considerando as dificuldades advindas das questões culturais camufladas em determinadas construções, o que dizer, então, de estruturas morfossintáticas mais complexas e, no entanto, aparentemente, idênticas à Língua materna, por sua organização estrutural?

A fim de elucidar questões sobre o tratamento dado a aspectos dessa natureza por alunos de um Curso de Letras - Licenciatura em Espanhol, é que esta pesquisa começou a ser delineada. Partindo das conclusões de Ortega (2005), buscou-se observar a forma como futuros professores de E-LE percebem as diferenças pragmáticas entre o Espanhol e o Português, quanto às estruturas e aos usos das Orações Condicionais introduzidas pela conjunção SE. Estas construções foram escolhidas para esta pesquisa a) por apresentarem estruturas morfossintáticas semelhantes no Espanhol e no Português, inclusive no que se refere à grande ocorrência, em ambas as línguas, do uso da conjunção $S E$ (correspondente ao $S I$, no Espanhol); e b) por serem consideradas estruturas da mais alta complexidade por gramáticos e linguistas - Haimann (1978), Montolío (1999), Fernández Lanza (2008).

${ }^{2} \mathrm{O}$ conceito de subtexto, elaborado por Vygostsky (2008), refere-se a um pensamento oculto por trás do que foi ou não dito: um pormenor gramatical pode, às vezes, modificar todo o teor do que se diz. (Vygotsky, 2008, p.160)

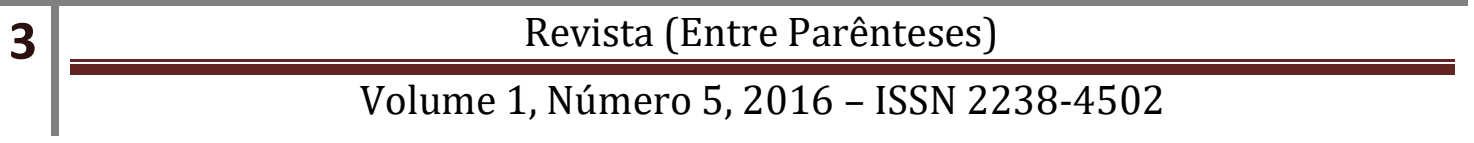




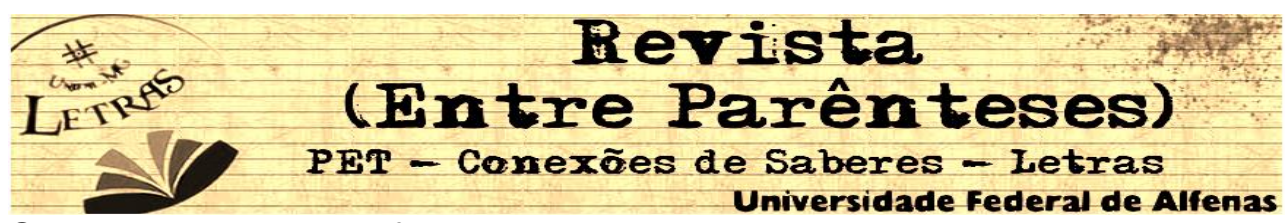

Considerando as dificuldades causadas pela semelhança entre as duas línguas, agravadas pela complexidade da estrutura das Orações Condicionais, este trabalho buscou evidenciar as aproximações e os distanciamentos existentes nessas estruturas gramaticais entre o Português e o Espanhol e identificar como os licenciandos percebem as diferenças de sentido dadas pelos elementos pragmáticodiscursivos presentes na construção dessas estruturas, por meio de análise sobre a forma como aqueles "teorizaram" e explicaram as estruturas condicionais a partir de suas percepções como falantes nativos do Português.

\section{As Orações Condicionais}

Os gramáticos e linguistas consultados são unânimes quanto à definição das Orações Condicionais, seja no Português, seja no Espanhol, basicamente, como um enunciado complexo composto por dois enunciados simples que estabelecem uma relação entre uma hipótese ou condição e sua realização ou não. Sua forma mais comum será: Se S1, então S2, na qual S1 denomina-se antecedente, prótase ou hipótese e $S 2$ consequente, apódose ou tese.

Tal definição não contempla alguns elementos que conferem às Condicionais um alto grau de complexidade. Consideremos que a relação $S 1$, $S 2$ se dá mediante um ato linguístico, para o qual contribuem sujeitos de um discurso que compartilham informações, conhecimentos e conceitos que envolvem aspectos socioculturais, além de discursivos. Mais para além, especificamente nesta construção, a relação que se estabelece depende, também, de um desenvolvimento lógico, pois o grau de possibilidade de realização da hipótese ou condição depende do atendimento de premissas ou condições para um resultado válido/verdadeiro ou não válido/falso.

Fernández Lanza (2008), alerta para a diferença entre a implicação que há entre as premissas e a conclusão de um argumento lógico dedutivo e a relação entre antecedente e consequente de uma Condicional. Em sua pesquisa com falantes nativos do Espanhol, ele constatou que, apesar de haver implicações lógicas na avaliação dos antecedentes e consequentes, o ato linguístico se dá pela elaboração de forma lógica, que contrasta VERDADE/FALSIDADE, mas se resolve por meio de um conhecimento prévio e uma construção semântica, que atribui o valor de VALIDADE/NÃO VALIDADE. 


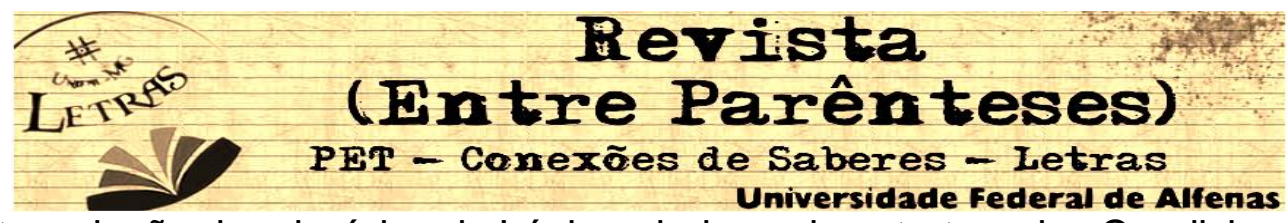

Essa inter-relação de princípios da Lógica, dados pela estrutura das Condicionais e por conhecimentos situacionais e culturais, trazidos pelos sujeitos da enunciação, confere extrema complexidade a esse tipo de construção.

Com relação à construção Se S1, então S2, encontramos em Perini (2010) uma abordagem gramatical que atenta para a relação filosófica da estrutura, ao organizar suas definições com foco no conectivo e não nas orações, com um tratamento específico para o estudo da conjunção SE como integrante do que ele chama de Modo Governado. Segundo ele, o conectivo que introduz uma oração subordinada pode governar o modo dessa oração e o conectivo $S E$, por apresentar quatro usos possíveis, de acordo com as correlações modo-temporais que se estabelecem, é uma conjunção "peculiar e merece um estudo separado".

No escopo desta pesquisa, interessam-nos três dessas correlações modotemporais: as referentes ao Se condicional, que pode co-ocorrer com o Indicativo ou com futuro do Subjuntivo para expressar uma condição, o Se contrafactual que utilizando o imperfeito do Subjuntivo denota algo que não é verdadeiro ou provável e o Se factivo que exprime um fato, sempre com o verbo no Indicativo.

Matte Bon (1995) afirma que no Espanhol há várias formas de expressar condições, destacando a relação modo-temporal escolhida pelo falante para externar sua percepção quanto ao grau de possibilidade de realização ou não da ação enunciada. Quanto maior a possibilidade de realização, no presente, no futuro, ou já efetivada no passado, utiliza-se o modo Indicativo; já diante da impossibilidade ou menor probabilidade de realização, a oração condicional adotará o modo Subjuntivo. Matte Bon classifica as orações como possíveis ou reais, irreais e eventuais.

Moura Neves (2000) se apoia em Haimann (1978) quando afirma não haver definições satisfatórias para as construções condicionais. Comenta que em geral os estudos se atêm à construção se $S 1, S 2$, desprezando a complexidade da estrutura. A maioria deles organiza as construções condicionais da seguinte forma: denomina-se prótase $\boldsymbol{p}$ a oração subordinada e apódose $\boldsymbol{q}$, a oração principal. Considerando a relação que se estabelece entre $p$ e $q$, realiza-se um período hipotético visto que a condição para a realização $\Rightarrow$ consequência/resultado da resolução da condição enunciada. Assim configuram-se três possibilidades, próximas às classificações de Revista (Entre Parênteses)

Volume 1, Número 5, 2016 - ISSN 2238-4502




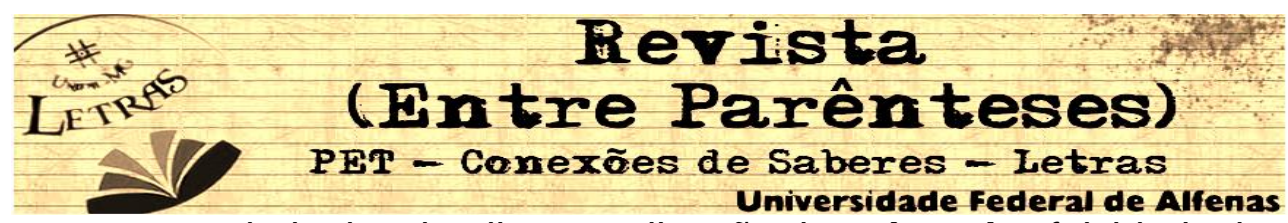

outros autores: a verdade de $\mathbf{p}$ implica a realização de $\mathbf{q} \rightarrow$ real; a falsidade de $\mathbf{p}$ implica a não-realização de $\mathbf{q} \rightarrow$ irreal e a potencialidade de $\mathbf{p}$ implica eventualidade de $\mathbf{q} \rightarrow$ eventual. Porém, com relação ao subtipo reais, Moura Neves (2000, p. 836) questiona sua denominação, pois "não se pode falar em realidade, em referência ao que aparece num enunciado, já que a realidade não se confunde com a linguagem: real ou não-real". Ela considerara que a proposição afirma não a realidade de um estado de coisas, mas sim a factualidade do que é dito, daí, adotar a terminologia real/factual. Da mesma forma, para o subtipo irreais, Moura Neves adota irreal/contrafactual.

Montolío (1999) afirma que as Orações Condicionais são, provavelmente, o tipo mais complexo de expressão composta por constituírem uma das principais formas de o falante expressar sua capacidade de imaginar situações diferentes das reais e, por isso, exigem uma análise que combina elementos gramaticais, semânticos e pragmáticos. Em sua concepção, é questionável ter por base que toda a oração condicional implica a formulação de uma hipótese ao considerar que uma condição que se refere a um evento passado não pode ser hipotética, visto já ter se realizado. Assim, a autora considera que uma condição apresenta uma noção mais ampla que uma hipótese e, portanto, as condicionais hipotéticas podem ser consideradas com um subconjunto das orações condicionais.

Coincidindo com Moura Neves (2000), Montolío (1999) chama a atenção para o fato de que um enunciado, como ato de fala, não pode ser classificado considerando a ocorrência de fenômenos reais. Trata-se de uma relação entre falantes na qual o autor do enunciado pede ao seu ouvinte que compartilhe e o acompanhe na situação hipotética que ele criou. Dessa forma, o falante expressa um estado de coisas que, com base na realidade que ele conhece, considera factível ou não no momento em que o apresenta. Assim, o uso do modo Indicativo denota situações consideradas factuais ao passo que, ao contrário, considerando a incerteza ou a impossibilidade de realização, utiliza-se o modo Subjuntivo.

Ainda que questionem a fragilidade da utilização de conceitos de realidade e irrealidade atribuídas a enunciados que exprimem declarações sobre um "estado de coisas", tanto Moura Neves quanto Montolío desenvolveram em seus estudos uma análise das construções Condicionais que as classifica em três subtipos: factuais Revista (Entre Parênteses)

$$
\text { Volume 1, Número 5, } 2016 \text { - ISSN 2238-4502 }
$$




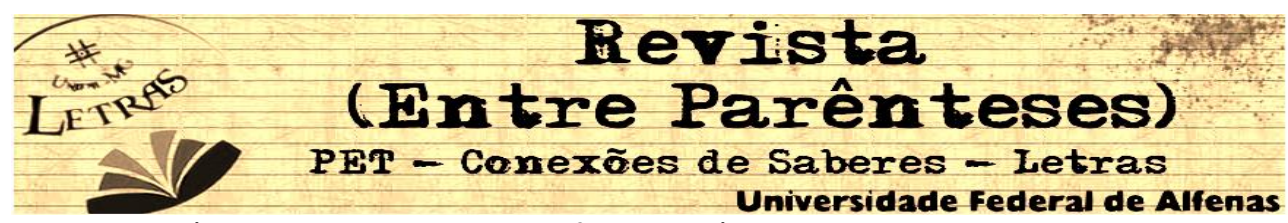

/reales, eventuais/potenciales e contrafactuais/irreales, que denotam maior ou menor certeza de realização, a partir de um ponto de vista modo-temporal. Vale ressaltar que as ocorrências apresentadas pelas pesquisadoras não abrangem a totalidade das possíveis combinações, uma vez que o seu trabalho se centrou em corporalinguísticos que não poderiam dar conta de todos os tipos de produção linguística no que se refere às Orações Condicionais. Mas, ainda assim, são representativas e apontam para possíveis interpretações de construções condicionais não relatadas por elas.

Observou-se que somente 12 combinações modo-temporais encontram equivalência entre as quarenta e seis apresentadas para o Português e as vinte apresentadas para o Espanhol, além de diferenças na classificação quanto à graduação de possibilidade de realização das ações apresentadas nas orações principais. Algumas dessas "lacunas" têm explicação gramatical, como é o caso das ocorrências que utilizam o futuro do Subjuntivo, em Português, devido a este tempo verbal estar em desuso no Espanhol, substituído pelo presente de Subjuntivo e, em alguns casos, ainda que não amplamente documentados, pelo pretérito imperfecto do Subjuntivo. Por outro lado, o falante de Português tem a opção do uso do infinitivo pessoal ou flexionado, inexistente no Espanhol. Segundo Maurer Júnior (1968), citado por Sandes (2001, p. 38), o infinitivo flexionado do português "é uma notável peculiaridade do português entre as línguas da família românica".

Esses "vazios de equivalência" podem ser uma das causas das dificuldades de interpretação e produção de falantes de Português no processo de aprendizagem do Espanhol. Ainda mais complexo é compreender as intenções e os entendimentos explicitados nos enunciados que, de acordo com as combinações modo-temporais, denotam maior ou menor grau de realização, entrando no campo pragmático-discursivo, para o qual os aprendizes parecem não estar atentos ou preparados.

\section{Estrutura da pesquisa e análise dos dados}

O corpus para este estudo foi obtido por meio de algumas atividades aplicadas a alunos do $2^{\circ}, 4^{\circ}, 6^{\circ}$ e $8^{\circ}$ períodos, regularmente matriculados no Curso de Letras Espanhol - Licenciatura, da UNIFAL-MG que, de forma voluntária, responderam a questionários e testes aplicados no segundo semestre letivo de 2014. A escolha de Revista (Entre Parênteses)

Volume 1, Número 5, 2016 - ISSN 2238-4502




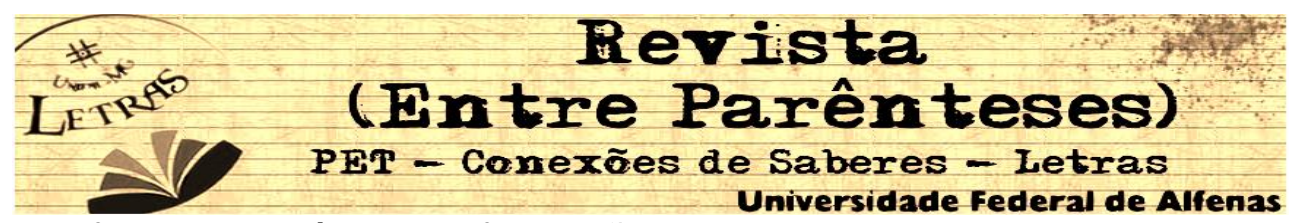

alunos de diferentes estágios de formação teve como objetivo possibilitar realizar um estudo comparativo que buscasse evidenciar de que forma esses alunos relacionam a consciência sócio-discursiva e a competência comunicativa/linguística adquirida.

As questões que se buscou elucidar foram: a) é possível que, independentemente do nível de domínio da língua, o aluno seja capaz de identificar elementos pragmáticos que subjazem no discurso? b) a aprendizagem desses elementos está relacionada ao conhecimento avançado da língua? Assim, no primeiro momento, foi aplicado um questionário com o objetivo de traçar o perfil acadêmico e caracterizar os sujeitos quanto aos seus conhecimentos com relação à cultura e ao conhecimento da língua espanhola anterior à graduação; seus objetivos e motivação para escolha do Curso de Letras Espanhol - Licenciatura.

No passo seguinte, os sujeitos tiveram de resolver atividades de tradução e interpretação, com o objetivo de aferir possíveis alterações que, acreditamos, ocorrem na maneira como passam a "pensar sobre a língua", diante da exposição ao Espanhol no decorrer da graduação. A primeira atividade, de tradução e interpretação, baseada em Bruno (2006), apoiou-se na definição de categorias de análise baseadas em características comuns dos elementos identificados, através dos questionários, e das semelhanças e diferenças entre as estruturas Condicionais em Espanhol e Português. Baseados em conhecimentos prévios e demandando competência linguística, os exercícios buscaram demonstrar se o uso que os alunos fazem das Condicionais é condizente com a visão que têm dessas estruturas e se a percepção que têm dessas construções em língua estrangeira são postas em prática na ação discursiva.

A segunda atividade teve como objetivo aproximar o sujeito da ideia de factibilidade da ação, característica de enunciados condicionais, por meio de uma gradação do realizável ao não realizável, para duas situações apresentadas com variações modo-temporais. E a terceira e última atividade exigiu que o sujeito analisasse a diferença de sentido e de probabilidade de realização entre enunciados para uma mesma situação, expressos em Português e Espanhol. Esta tarefa buscava colocar o sujeito em situação de reflexão quanto às combinações modo-temporais possíveis em cada língua e como essa combinação pode, ou não, afetar o sentido.

Revista (Entre Parênteses)

Volume 1, Número 5, 2016 - ISSN 2238-4502




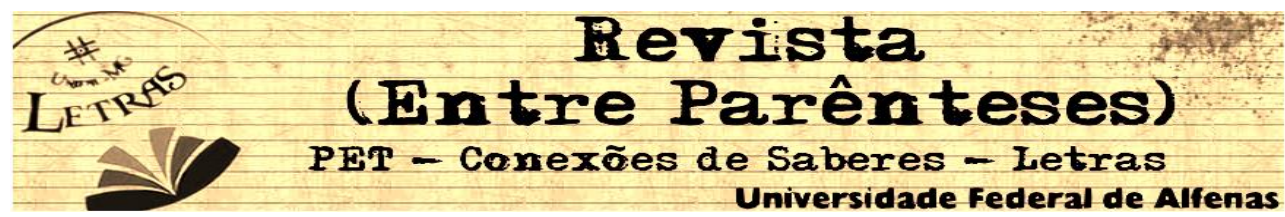

A análise dos dados dos testes foi feita com base no cruzamento das questões aplicadas, seguindo a metodologia utilizada por Bruno (2006, p. 88) analisando a produção dos sujeitos para cada item de avaliação: rascunho mental, conhecimentos prévios e subtexto.

\section{Atividade $1^{3}$}

A fim de verificar a interpretação de um enunciado em Espanhol, a primeira atividade apresentou dois textos, uma tirinha, de Quino ${ }^{4}$, e o fragmento de um texto de Villalba ${ }^{5}$, para os quais foi solicitado elaborar a reescritura em Espanhol e sua versão em Português. Ao final, o sujeito deveria refletir sobre o processo de construção de sua versão e a explicitar as dificuldades encontradas e os elementos facilitadores para a reescrita, indicando conhecimentos e raciocínios a que recorreu para a atividade.
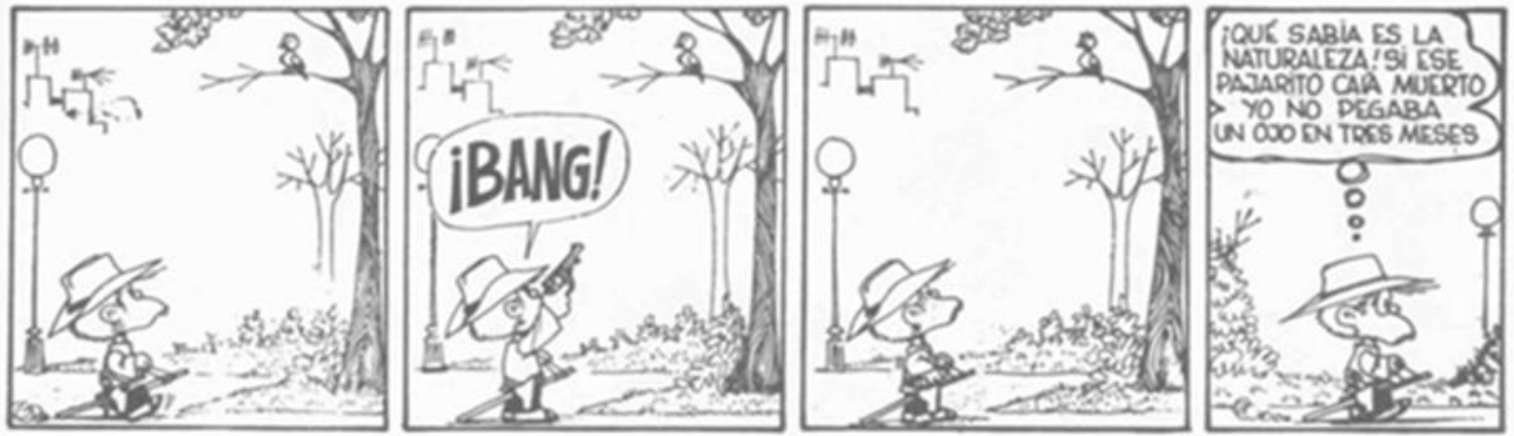

QUINO. Diez aflos con Mafoldo. 23 ed. Buenos Aires: Ediciones de lo Flor, 2008. p.147

El único consejo que se puede dar es que lo abran y empiecen a leerlo. $\underline{\mathrm{Si}}$ una vez empezado no les interesa. menos me van a creer a mi que a Cervantes. Pero creo que si un lector lo empieza no lo dejará. Si es algo vago, puede saltarse sin miedo algunas novelas intercaladas y seguir de cerca a Don Quijote y Sancho. Merecerá la pena. Ignacio Arellano - Extraido de VIILALBA, Terumi Koto Bonnet et al. Formación en español: lengua y cultura : dramatización: $9^{\circ}$ año. Manual del profesor. Curitiba: Base Editorial, 2012. p.13)

\footnotetext{
${ }^{3}$ As construções elaboradas pelos sujeitos da pesquisa foram transcritas exatamente como foram escritas.

${ }^{4}$ QUINO. Diez años com Mafalda. 23.ed. Buenos Aires: Ediciones de la Flor, 2008, p. 147.

${ }^{5}$ VILLALBA, Terumi Koto Bonnet et al. Formación en Español: lengua y cultura: dramatización: $9^{\circ}$ año. Manual del profesor. Curitiba: Base Editorial, 2012, p.13.

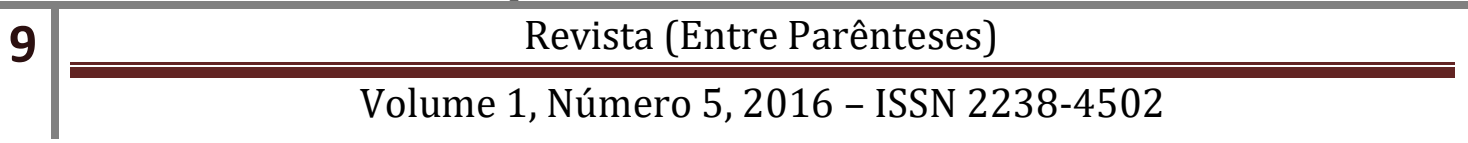




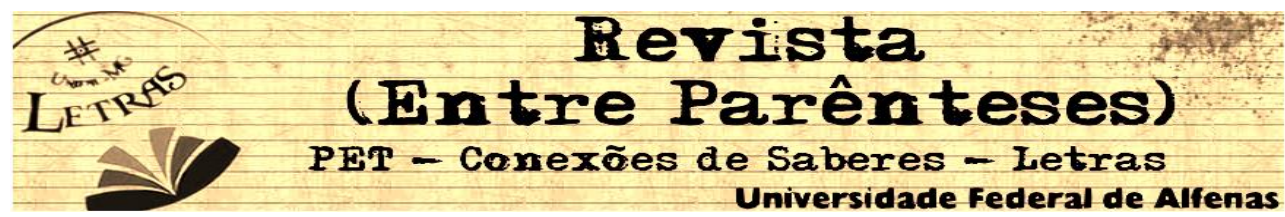

A análise deste primeiro teste foi realizada agrupando-se a produção dos sujeitos por tarefa. Primeiramente, foram tratadas as (re)construções em Espanhol, para a tirinha e para o fragmento, com o objetivo de analisar as estratégias utilizadas pelos sujeitos para esse tipo de atividade que apresentava como mais um fator de dificuldade ter algum conhecimento na língua espanhola. Na sequência, foram analisadas as construções em Português que, apesar de utilizarem a língua materna, demandavam a interpretação correta do enunciado em Espanhol.

Apresentam-se abaixo as sentenças destacadas para o trabalho dos sujeitos e a descrição modo-temporal dos verbos que as compõem:

\section{Tirinha}

¡Qué sabia es la naturaleza! Si ese pajarito caía muerto, yo no pegaba un ojo en tres meses.

[C: imperfecto de indicativo / P: imperfecto de indicativo]

\section{Fragmento}

El único consejo que les puedo dar es que lo abran y empiecen a leerlo. Si una vez empezado no les interesa, menos me van a creer a mí que a Cervantes

[C: presente de indicativo / P: [ir a + infinitivo] (sentido de futuro) de indicativo]

Segundo as observações de Montolío (1999), as construções em questão apresentam uma situação REAL/FACTUAL com relação aos efeitos de sentido proporcionadas pelo uso do modo Indicativo, pois, "Cuando un hablante utiliza una forma verbal de indicativo en la prótasis, denota un estado de hechos que, a tenor de su conocimiento sobre la realidad, considera factibles en el momento temporal en que los presenta" (MONTOLÍO, 1999, p. 3659).

Sendo assim, podemos interpretar que a escolha de Quino aproxima a possibilidade da morte do passarinho e a certeza da consequência do acontecimento (não dormir por três meses), valorizando, assim, a sabedoria da Natureza que impediu tal tragédia. Da mesma forma, Villalba, no trecho selecionado para o teste, acredita que, para gostar de ler Dom Quixote, basta começar, pois se o leitor não for convencido por Cervantes, remota é a possiblidade de que ele, Villalba, consiga-o. 


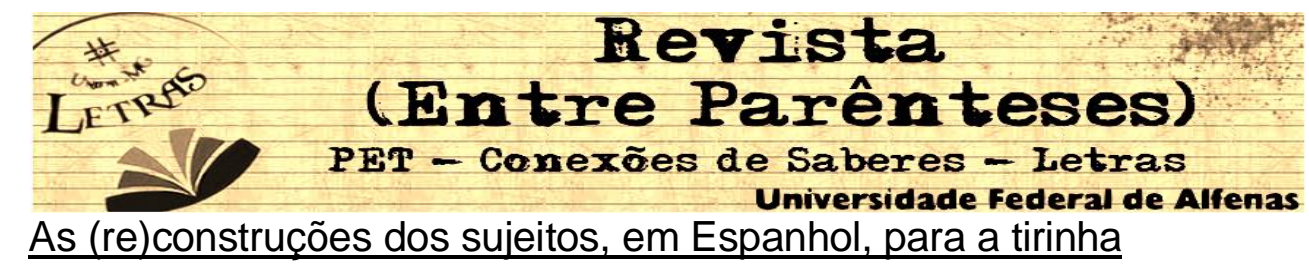

Observando as produções dos sujeitos, pôde-se verificar que as construções apresentaram uma variação modo-temporal entre [imperfecto de subjuntivo + condicional], [presente de indicativo + condicional], [pluscuamperfecto de subjuntivo + condicional] e [imperfecto de subjuntivo + imperfecto de indicativo]. Alguns não souberam responder e somente um sujeito elaborou uma construção mais próxima à original e ao seu sentido: "si esse pajarito se moría yo no dormia por três meses", mas declarou não saber explicar sua escolha.

Os sujeitos que adotaram o modo Indicativo na prótase, justificaram ter-se baseado na maior possibilidade de realização ou em correlações temporais. Aqueles que utilizaram, ainda que na apódose, o modo Indicativo, declararam não estar seguros de sua compreensão, o que permite inferir que tenham adotado o mesmo modo do modelo de forma imitativa, como se observa em a) "Que bela es la naturaleza, si ese pajarito muere yo no duermeria por tres meses". Ao adotar o modo Indicativo, o sujeito mantém a factualidade explicitada no enunciado original, diferente da combinação dos pretéritos de Subjuntivo + Indicativo utilizados em b) "Qué sabia es la naturaleza. Sí este pajarito cayera muerto, yo no pegaba un ojo en tres meses.", que, conforme Montolío, denota uma eventualidade, assim como para Moura Neves, sendo que esta vê, também, a possibilidade de uma ideia de contrafactualidade.

Em oposição ao efeito de sentido que denota o uso do Indicativo, a construção com o Subjuntivo denota uma realização pouco provável, não necessariamente impossível. Porém, combinado com um valor temporal que se refere a uma ação atual com relação ao momento do enunciado, tem como efeito de sentido, segundo Montolío (1999), que "La suspensión de la realidad se convierte en imposibilidad absoluta" ( $p$. 3661). Ao utilizar construções com tempos verbais do modo Subjuntivo, os sujeitos denotam uma ideia de menor possibilidade de realização do fato relatado. Destaca-se o uso do pluscuamperfecto de subjuntivo em algumas construções, denotando sua total impossibilidade de realização, ou seja, afastando-se completamente da intenção original apresentada.

Ou seja, ainda que declarem "pensar nos tempos verbais", demonstrando reconhecer que efeitos de sentido podem ser explicitados conforme o modo e o tempo Revista (Entre Parênteses)

Volume 1, Número 5, 2016 - ISSN 2238-4502 


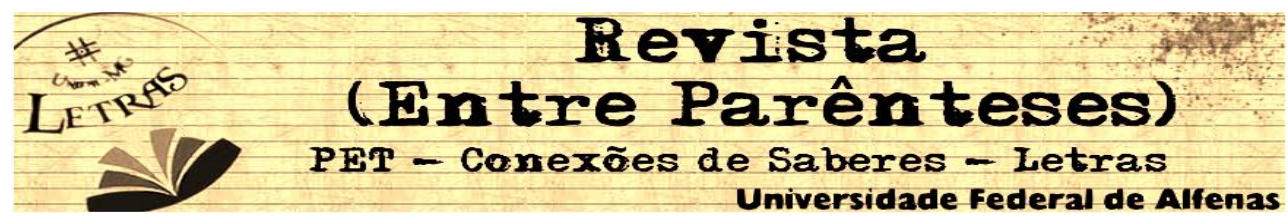

verbal empregados, alguns dos sujeitos da pesquisa parecem não se atentar para a alteração que as combinações modo-temporais denotam com relação ao grau de possibilidade de realização das ações presentes nas sentenças.

\section{As (re)construcõoes dos sujeitos, em Espanhol, para o fragmento}

Os enunciados elaborados pelos sujeitos, nesta atividade, apresentaram, na grande maioria, uma construção modo-temporal idêntica à do enunciado original [presente de indicativo + [ir + a + infinitivo] (futuro) de indicativo] como se observa em: "Si no les interesa cuando empezado, van a creer menos a mí que a Cervantes." ou "Si después de haber empezado a leerlo no les interessa, van a acreditar menos em mí que em Cervantes".

Somente um sujeito reproduziu o enunciado utilizando o modo Subjuntivo na prótase [pretérito perfecto de subjuntivo + [ir a + infinitivo] (futuro) de indicativo]: "Si una vez iniciado no les haya interesado, menos e van a creer a mí que a Cervantes.", mas a sua explicação, que dizia que se baseou nas disciplinas de língua espanhola e tradução, sem nenhum detalhe sobre seu raciocínio ou conhecimentos aos quais recorreu, fugiu à proposta da questão que era buscar suas impressões e conhecimentos gerais os quais contribuíram com sua escolha. Isso nos permite inferir que sua preocupação, ao produzir sua versão para o enunciado, tenha sido mais voltada para um viés gramatical do que semântico, o que prejudicou nossa percepção sobre seu "rascunho mental" para a elaboração desta atividade.

\section{As construções dos sujeitos, em Português, para a tirinha}

Nessa proposta de atividade, predominaram as construções com [pretérito de subjuntivo + futuro do pretérito de indicativo]: "se o passarinho morresse, eu não poderia dormir por três meses" e [pretérito de subjuntivo + imperfeito de indicativo]: "Que sabia é a natureza! Si esse passarinho caísse morto, eu não dormia por três meses." Alguns sujeitos não souberam responder.

Da mesma forma que Montolío (1999), Moura Neves (2000, p. 848) aponta o uso do modo Indicativo para construções factuais: 


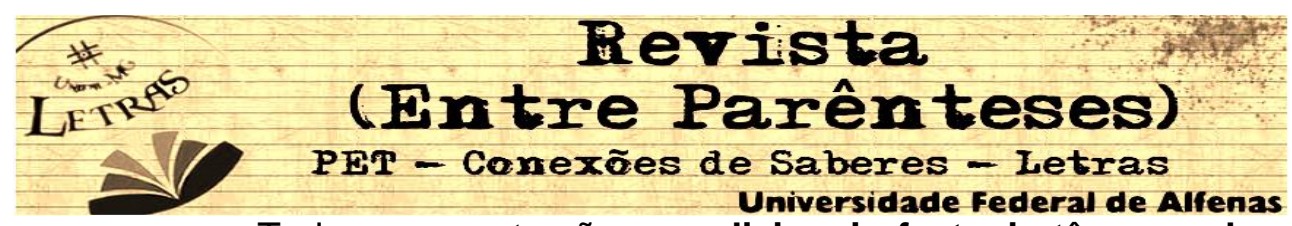

Todas as construções condicionais factuais têm o verbo no modo indicativo em ambas as orações, o que configura exatamente a factualidade das construções. A oração principal pode ser de presente, de passado ou de futuro, mas a oração condicional só vem no presente ou no passado, configurando factual no presente, ou factual no passado, respectivamente.

Significa dizer que o enunciado original produzido em Espanhol é regido por uma ideia representada de forma coincidente em Português. No entanto, os sujeitos da pesquisa, ainda que falantes nativos de Português, utilizaram em $100 \%$ de suas produções, na oração condicional, o modo Subjuntivo, possivelmente como forma de marcar uma diferença entre as duas línguas. O esquema modo-temporal utilizado, segundo Moura Neves (2000, p. 850) configura uma construção contrafactual,

As construções condicionais contrafactuais têm 0 verbo da subordinada no modo subjuntivo, e numa forma passada (pretérito imperfeito e pretérito mais-que-perfeito). Assim, só há contrafactual no passado, já que também o verbo da oração principal é sempre passado, aí incluído o futuro do pretérito composto. (MOURA NEVES, 2000)

Ou seja, $100 \%$ dos enunciados elaborados em Português pelos sujeitos da pesquisa apresentam uma ideia de contrafactualidade em oposição à ideia do enunciado original. Por outro lado, surpreendentemente, a factualidade do enunciado original foi reproduzida em $50 \%$ dos enunciados produzidos na reescrita em Espanhol.

\section{As construcõoes dos sujeitos, em Português, para o fragmento}

Da mesma forma como ocorreu no processo de reescrita em Espanhol, nas construções em Português a maioria dos sujeitos elaborou versões utilizando estruturas muito próximas à do enunciado original: [infinitivo + [ir + infinitivo] (futuro) de indicativo] e [presente de indicativo + [ir + infinitivo] (futuro) de indicativo]: "Se não interessar a vocês uma vez que começado, vão acreditar menos em mim que em Cervantes." / "Se uma vez começado não Ihes interessa, menos vão crer em mim que a Cervantes."

Também neste caso, um dos sujeitos (outro que não aquele da reescrita em Espanhol), motivado por uma preocupação com aspectos gramaticais, conforme sua

Volume 1, Número 5, 2016 - ISSN 2238-4502




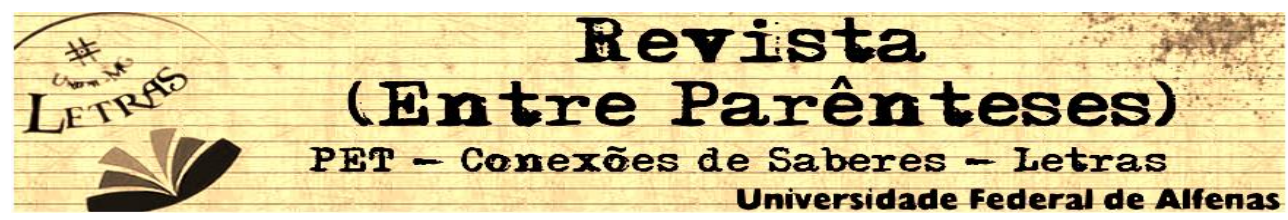

justificativa "Reescrever com o máximo de proximidade de sentido é um pouco mais difícil, ainda mais porque é uma sentença solta dentro de um texto. Talvez os tempos e modos verbais em espanhol sejam os que mais exigem atenção", utilizou o modo Subjuntivo [presente de subjuntivo + futuro do presente de indicativo]: "Se, no entanto, tendo começado a lê-lo, não tenham interesse em prosseguir, seguramente, terei menos credito que Cervantes." desconsiderando a factibilidade denotada pelo uso do Indicativo e dando à sentença um sentido de menor possibilidade de realização.

Como observado na atividade de reescrita em Espanhol e conforme Montolío (1999) e Moura Neves (2000), a construção revela a certeza de realização dada pelo sujeito do enunciado. O fato de $90 \%$ das construções elaboradas pelos sujeitos de pesquisa serem praticamente idênticas ao enunciado original permite afirmar que este exemplo apresenta uma construção de sentidos mais próxima de construções produzidas pelos falantes de português. Estranhamente, todos os sujeitos afirmaram ter maior dificuldade de interpretação com este enunciado que com o anterior, mas houve maior proximidade com relação à possibilidade de realização, como se observa nesta construção: "Se, no entanto, tendo começado a lê-lo, não tenham interesse em prosseguir, seguramente, terei menos credito que Cervantes".

Analisando as produções dos sujeitos, para este primeiro teste, observou-se que, com relação ao "rascunho mental", 6 em $90 \%$ das construções os sujeitos apresentaram uma coerência de compreensão do "subtexto", posto que, em suas declarações a respeito de seu entendimento sobre os textos, perceberam a possibilidade de realização das ações, ainda que utilizando, em $50 \%$ dos casos da reescrita em Espanhol, formas verbais do Subjuntivo e adotando, de forma integral, esse modo na elaboração dos enunciados em Português.

Considerando que as construções para o fragmento, tanto em Espanhol quanto em Português, mantiveram-se muito semelhantes à estrutura modo-temporal do texto original, nossa análise se concentrou nas produções referentes à tirinha. Nestas, devido aos sujeitos terem mantido um esquema modo-temporal próximo ao do enunciado

\footnotetext{
${ }^{6}$ Processo referido em Vygotsky (2008, p. 474) no qual “A passagem da linguagem interior para a exterior é uma complexa transformação dinâmica - uma transformação da linguagem predicativa e idiomática em uma linguagem sintaticamente decomposta e compreensível para todos”.
} Revista (Entre Parênteses) Volume 1, Número 5, 2016 - ISSN 2238-4502 


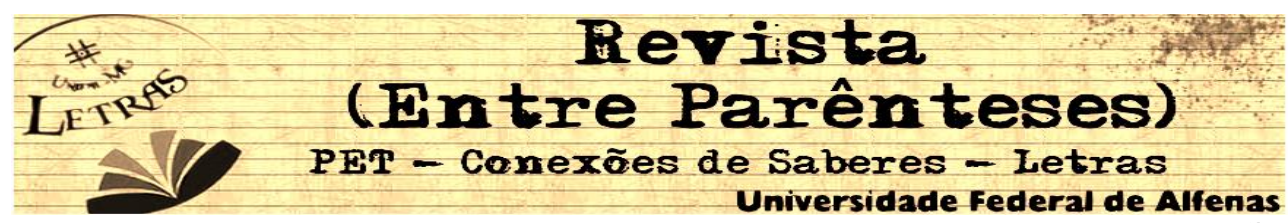

original no momento da reescrita em Espanhol e alternarem para construções com o modo Subjuntivo nas produções em Português, pode-se afirmar que sua reescrita foi imitativa mais que interpretativa, já que, ao elaborar os enunciados em Português, a sutileza da escolha de Quino não foi percebida. Esperava-se que os sujeitos da pesquisa identificassem que o personagem esboçava alívio por não ter conseguido matar o pássaro, embora fosse bem possível matá-lo. Caso isso acontecesse, ele morreria de remorso. O pássaro não morreu, ele está bem.

Nas respostas apresentadas, em $70 \%$ dos casos, nas traduções para 0 Português, os sujeitos, em suas declarações no momento de exposição do processo de interpretação e enumeração de elementos que contribuíram para a compreensão do enunciado ("rascunho mental"), explicitaram perceber a efetividade de realização dada pelo uso dos verbos em [Indicativo + Indicativo]. No entanto, contraditoriamente, utilizaram o [pretérito de subjuntivo + futuro do pretérito de Indicativo] "Que boa é a natureza, se esse pássaro caísse morto, eu não fecharia os olhos por três meses" que, segundo Moura Neves, caracteriza uma composição que evidencia uma possibilidade/eventualidade de realização.

Para a reescrita em Espanhol, os sujeitos da pesquisa, seguindo o mesmo "rascunho mental", utilizaram, em $60 \%$ dos casos, a combinação [pretérito pluscuamperfecto de subjuntivo + condicional] “¡Qué sabia es la naturaleza! Si ese pajarito hubiese caído muerto yo no pegaría un ojo en tres meses". Segundo Montolío, essa construção caracteriza uma maior incerteza ou impossibilidade de realização, alterando sutilmente a intenção original do sujeito do enunciado. Ainda que os sujeitos declarem, conscientemente, reconhecer a factualidade para a realização das ações, citando, inclusive, conhecimentos gramaticais relativos ao efeito de sentido denotados pelo modo Indicativo, quando reelaboram os enunciados o fazem, naturalmente, utilizando o modo Subjuntivo.

A recorrência na escolha do modo Subjuntivo, tanto para as construções em Português quanto em Espanhol, confirma as observações de Perini (2010, p. 200) sobre o modo nas orações que ele chama de factuais, para o qual postula a seguinte regra: "Quando uma oração subordinada expressa um fato (na opinião do falante), seu verbo fica no indicativo se esse fato é asserido, e no subjuntivo se ele é pressuposto.". Desse 


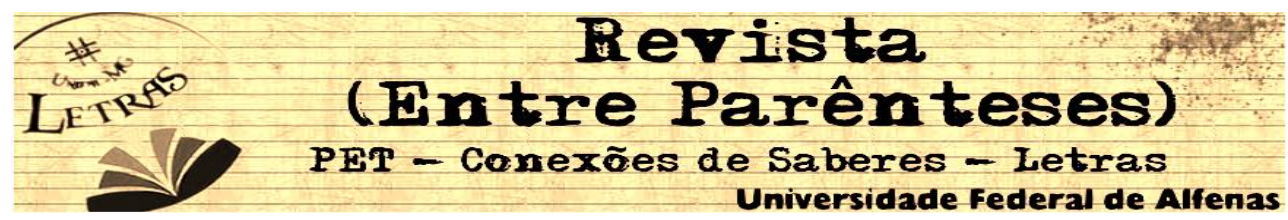

modo, associa-se uma situação de condição ou hipótese com o modo Subjuntivo, mesmo quando o sujeito afirma não haver compreendido ou quando produz enunciados incompatíveis com o rascunho mental explicitado. É o caso dos enunciados: "Como es sabia la naturaleza. Yo no pegaba otro pajarito si ese no "caisse" muerto" / "que sábia é a natureza, se esse passarinho não caísse morto eu não vería outro em 3 meses".

\section{Atividade 2}

Esta atividade teve como objetivo verificar o quanto os alunos conseguiam perceber os efeitos de sentido que as combinações modo-temporais denotam, em Espanhol, com relação à factibilidade de realização. Assim, o que se buscava era verificar se os sujeitos eram capazes de identificar diferenças de sentido entre construções que apresentavam apenas mudanças quanto à escolha de aspectos modotemporais dos verbos utilizados, reconhecendo particularidades do Espanhol, que muitas vezes são diferentes do Português.

Ao serem confrontados com enunciados semelhantes quanto à situação de ocorrência, buscou-se provocar uma reflexão sobre como essa combinação pode, ou não, afetar o seu sentido. Eles deveriam apontar se os enunciados apresentavam situações realizáveis, prováveis, pouco prováveis, improváveis ou não realizáveis. 0 primeiro grupo de enunciados apresentou as seguintes variações:

a) Si llueve, haremos una buena cosecha.

b) Si hubiera llovido, hubiéramos hecho una buena cosecha.

c) Si lloviera, haríamos una buena cosecha.

Seguindo as considerações de Montolío, para os sentidos denotados pelas combinações modo-temporais, (a) [presente de Indicativo + futuro de Indicativo] apresenta plena condição de realização; (b) [pretérito pluscuamperfecto de Subjuntivo + pretérito pluscuamperfecto de Subjuntivo] denota uma situação sem condições de realização; e (c) [pretérito imperfecto de Subjuntivo + condicional] está entre o potencial e o irreal.

Observou-se que, no que se refere ao enunciado (a), os sujeitos, em sua maioria, dividiram-se entre realizável (4) e provável (4). Dois entenderam ser pouco Revista (Entre Parênteses)

Volume 1, Número 5, 2016 - ISSN 2238-4502




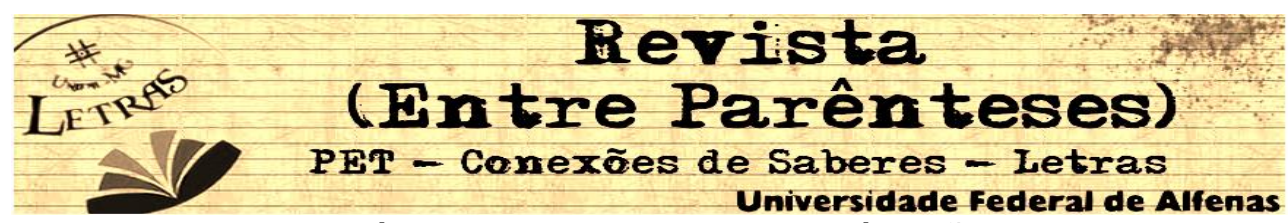

provável. Parece estranho, já que o modo Indicativo, até então, quase sempre, pareceu denotar, para os sujeitos, uma possibilidade de realização. No entanto, com base em Perini (2010), pode-se considerar que, como falantes de português, os sujeitos entenderam que o uso do futuro de Indicativo na oração principal denotaria uma falta de certeza para a realização da ação. O autor afirma que o futuro simples (haremos) é de uso muito raro pelo falante brasileiro, sendo considerado uma forma própria do padrão escrito e, normalmente expressado através de uma construção composta com o verbo auxiliar ir. Observando os exemplos que Moura Neves apresenta com este tempo verbal, em situações classificadas como factuais, o enunciado é construído com a forma composta [ir + infinitivo] $\rightarrow$ [SE você quer se promover, não vai ser às minhas custas] e para exemplificar situações de realização eventual, o exemplo apresentado adota a forma simples [SE ele pensa, verá o erro]. Assim, a opção dos sujeitos pela classificação da sentença como provável ou pouco provável, ou seja, eventual, encontra justificativa nas observações de Perini.

Em (b), seis sujeitos entenderam a construção como não realizável, enquanto que os demais entenderam como plenamente realizável (2) ou provável (2). Com base nas respostas e construções apresentadas nos testes anteriores, evidencia-se que, para os falantes de Português, além de o uso do Subjuntivo denotar uma maior impossibilidade de realização, o tempo verbal no passado denota algo terminado, sem condições de realização no futuro, o que se confirma considerando a resposta da maioria dos sujeitos para este enunciado. No entanto, o fato de a resposta dos demais sujeitos apresentar uma interpretação oposta, pode estar motivada pelo pretérito imperfecto de subjuntivo (hubiera) presente no tempo composto - pluscuamperfecto de subjuntivo - da oração condicional que, segundo Moura Neves, no tempo verbal mais próximo do português, o pretérito do subjuntivo, denota, em algumas combinações, uma eventualidade. É possível que estes sujeitos tenham desconsiderado que, neste caso, o verbo está na função de verbo auxiliar (hubiera llovido), em um tempo que atribui a ideia de contrafactualidade às Condicionais, segundo Moura Neves e Montolío.

Em (c), houve uma maior dispersão quanto ao sentido da construção: dois sujeitos a entenderam como improvável, quatro entenderam como pouco provável, dois como provável e dois como realizável. Pode-se dizer que as opções improvável, pouco Revista (Entre Parênteses)

Volume 1, Número 5, 2016 - ISSN 2238-4502




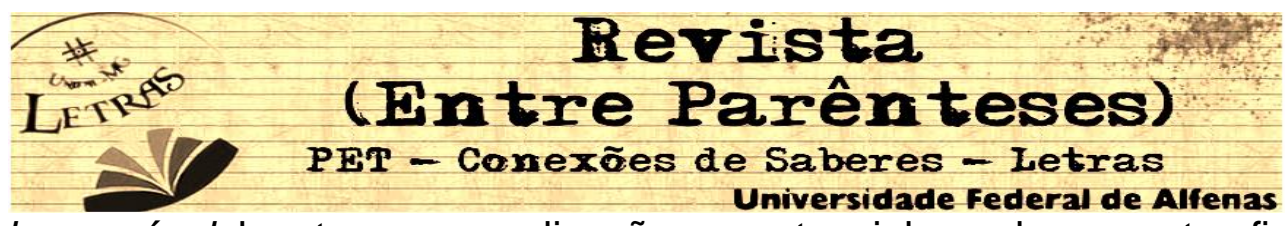

provável e provável denotam uma realização em potencial, sendo coerente afirmar que a maioria dos sujeitos interpretou os enunciados em conformidade com a classificação proposta por Montolío.

Cabe, então, uma análise específica para o entendimento de factualidade atribuída por dois sujeitos. Por um lado, pode-se pensar que os sujeitos não compreendem a combinação modo-temporal da sentença, já que seu conhecimento linguístico, conforme declarado por eles próprios, é o de iniciantes que ingressaram no curso faz um ano. Por outro, poder-se-ia considerar que, visto a presença do futuro do pretérito (condicional) na oração principal, segundo Moura Neves, denotar, em diversas combinações modo-temporais do português a eventualidade, neste caso, a construção com o pretérito imperfeito do Subjuntivo pode ter sido interpretada como uma realização futura, remota, mas realizável.

O segundo grupo de enunciados apresentou uma variação de combinações com uma maior semelhança de sentido, quanto ao grau de realização:
a)... si me toca la lotería, habría ido contigo
b)... si me tocara la lotería, hubiera ido contigo
c)... si me tocaba la lotería, iba contigo

Segundo Montolío, a combinação em (a) [presente de Indicativo + condicional perfecto] denota impossibilidade de realização, assim como a combinação que se apresenta em (b) [pretérito imperfecto de Subjuntivo + pretérito pluscuamperfecto de Subjuntivo]. Já a construção (c) [pretérito imperfecto de Indicativo + pretérito imperfecto de Indicativo], devido ao uso do modo Indicativo em ambas as orações, permite interpretar a situação como real/potencial.

Neste grupo de enunciados, para a construção (a), seis sujeitos a consideraram como irrealizável, ao passo que os outros sujeitos atribuíram-lhe a probabilidade de realização, opção que pode ser justificada pela presença do presente de Indicativo na oração condicional. Conforme Moura Neves, nas construções classificadas como factuais e eventuais predominam as combinações em que está presente o modo Indicativo no presente, passado ou futuro. 


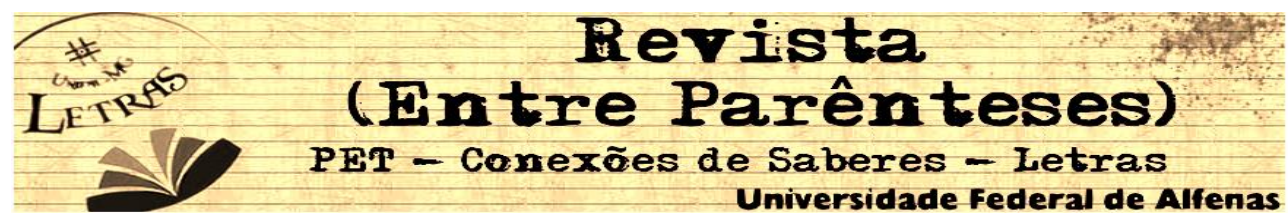

Em (b), aconteceu algo muito semelhante ao que ocorreu em (a). Seis sujeitos interpretaram o enunciado como irrealizável, sendo que cinco compõem o conjunto daqueles que também haviam considerado assim (a), e três atribuíram a possibilidade de realização. Essa inconstância nas respostas pode ser atribuída à insegurança que os sujeitos declaram ter com relação ao uso do Espanhol e que se apresenta de forma mais evidente ao serem colocados em situação de confronto com enunciados que apresentam, por sua estrutura, ideias aparentemente iguais. Novamente, o uso do modo Subjuntivo denota menor probabilidade de realização, como vai se evidenciando ao longo desta pesquisa e, igualmente, a presença do pretérito imperfeito de Subjuntivo (tocara) permite o entendimento de eventualidade.

Em (c), houve todos os tipos de interpretação possíveis: não sei (1); não realizável (1); improvável (2); pouco provável (1); provável (1) e realizável (4). Essa dispersão pode se justificar porque a construção [Indicativo + Indicativo], em ambas as sentenças, proporciona a ideia de factualidade e, ao ser combinada com um tempo do passado, denota menor grau de realização, provocando dúvidas de interpretação. Essa variação pode ser observada nos exemplos apresentados por Moura Neves (SE eu estava com a verdade, porque eu estava derrotado?) ou (Eu não estou vendo coisa nenhuma, SE João estava no bar, estava bêbado!) e Montolío (SI se iba a intentar una aproximación a la problemática de la planificación familiar en España, era fundamental recabar la opinión de todos los afectados) ou (SI me ocurría, no me daba por vencida), classificadas como factuais/reales e eventuais/potenciales, respectivamente. Assim, a opção da maioria dos sujeitos, variando entre a realização e a probabilidade de realização (em maior ou menor grau) da ideia proposta pelo enunciado, aproxima-se das definições teóricas às quais recorremos. 


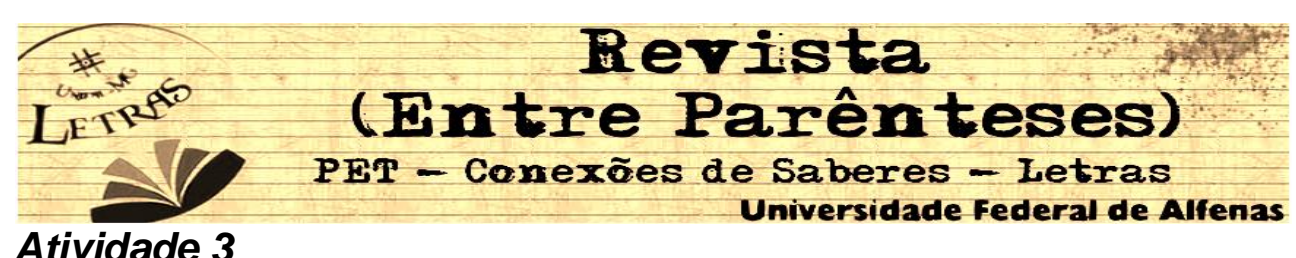

Atividade 3

Em cada grupo de enunciados abaixo (a e b), uma mesma situação é apresentada, em Espanhol e em Português. Para cada grupo, explicite a mensagem que foi transmitida e compare o sentido e a probabilidade de realização expressada entre as afirmativas (1) e (2). Você considera que ambas apresentam a mesma probabilidade de realização? Para você, ambas têm ou não o mesmo sentido (de frustração, de possibilidade de mudar o resultado...)?

(a.1) Si llego a saberlo a tiempo lo impido.

(a.2) Se tivesse chegado a saber disso a tempo, tinha impedido.

(b.1) Si hubiera sido dedicado, habría ganado el premio.

(b.2) Se eu fosse aplicado, obteria o prêmio.

Segundo Montolío, a perífrase llegar+a, em (a.1) marca a impossibilidade de realização sendo IRREAL; e Moura Neves define que o tempo composto do pretérito de subjuntivo, presente no enunciado (a.2) marca a ação como realizada e terminada, portanto imutável, ou seja, CONTRAFACTUAL.

Para a primeira situação, as respostas apresentadas se equiparam quanto ao entendimento de que não há possibilidade de mudança em nenhuma das situações (45\%), e aqueles que entendem que em (a.1) é possível reverter a ação e em (a.2) o fato está consumado (45\%). Este grupo de sujeitos justifica este entendimento devido ao uso do modo Indicativo em (a.1) e o modo Subjuntivo em (a.2). Declararam não haver entendido e não souberam responder $10 \%$ dos sujeitos, alegando não ter conhecimentos prévios de Espanhol por estarem no início do Curso de Letras.

No Português, segundo Moura Neves, o uso do Indicativo denota algo novo e com possibilidades de realização, ao passo que o Subjuntivo é utilizado frequentemente para as declarações CONTRAFACTUAIS. Este exemplo ilustra perfeitamente o conflito de produção de sentidos que o Indicativo apresenta para o falante de Português, em contraste com a possibilidade de interpretação no Espanhol. Observa-se, no quadro "Combinações modo-temporais X Tipos de condicionais", que a combinação de ambas as orações no modo Indicativo, para o Português, é predominante na construção de situações FACTUAIS e EVENTUAIS com uma única situação que denota CONTRAFACTUALIDADE, desde que combinado com uma forma de pretérito. Desse Revista (Entre Parênteses) 


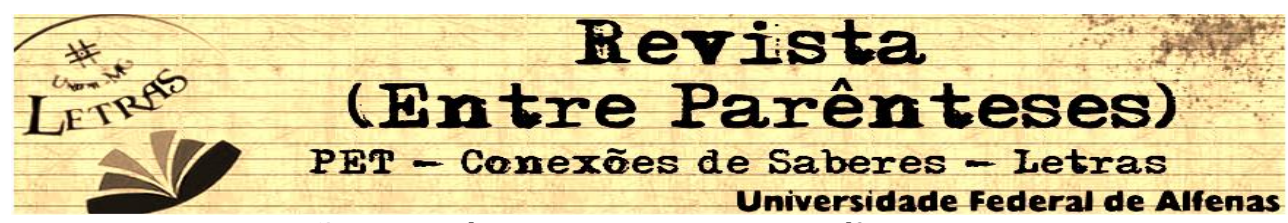

modo, o sentido de ação imutável, dado pela perífrase verbal llegar $+a$, passa despercebido para o falante de Português.

A segunda situação apresentou $100 \%$ das opiniões compatíveis com as possibilidades de realização, segundo Moura Neves e Montolío. O uso de pluscuamperfecto de subjuntivo no enunciado (b.1) denota, segundo Montolío, uma situação para a qual não há possibilidade de mudança, sendo então IRREAL. Da mesma forma, Moura Neves, classifica o enunciado (b.2) como CONTRAFACTUAL, mas apresenta, também, a possibilidade de alguma mudança, portanto EVENTUAL.

O fato de os sujeitos terem sido unânimes no entendimento de uma situação que não possibilita alterações pode ser atribuída ao efeito de sentido que o uso do modo Subjuntivo traz para os falantes de Português nas construções em que se declara uma situação que permite a pressuposição do fato ocorrido pelo receptor, já evidenciado por Perini (2010, p. 204) e conforme se observou em outras atividades e produções, mas, principalmente, pelo fato de apresentar fatos passados e, portanto, imutáveis.

\section{Conclusões}

Como se pôde observar, alguns estudos sobre a formação inicial de professores de Língua Estrangeira (LE) (Almeida Filho, 1992; Mizukami, 2004; Ortega, 2005; Paiva, 2005; Escandell Vidal, 2009) apontam a organização curricular como importante fator para a deficiência dessa formação. Esses pesquisadores concluíram que a carga horária reservada aos conteúdos específicos da LE é insuficiente para o desenvolvimento da competência comunicativa necessária aos futuros professores que, segundo Paiva (2005), não são estimulados à reflexão sobre a aquisição, ensino e aprendizagem da língua que vão ensinar.

No caso do ensino de Espanhol como Língua Estrangeira (E-LE), a imaginada proximidade entre o Espanhol e o Português constitui outro aspecto que afeta a qualidade da formação desse futuro docente que, segundo o professor Fernández López (1997), é um falso principiante que tende a transferir conceitos estruturais e culturais do Português para o Espanhol. E é na semelhança estrutural de algumas construções que componentes extragramaticais, destacados pela professora Escandell Vidal (2009), ficam camuflados e passam despercebidos ao aprendiz, comprometendo 


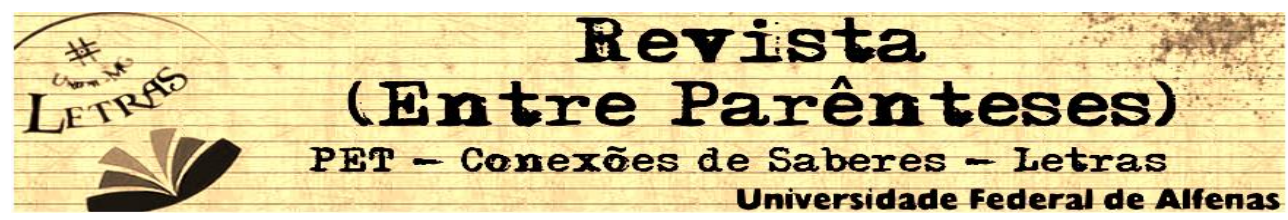

sua percepção de elementos pragmático-discursivos que subjazem as construções morfossintáticas e que codificam valores socioculturais do falante de Espanhol.

Essas dificuldades do aprendiz, falante de Português, na identificação de marcas culturais do Espanhol, por estarem implícitas nas estruturas morfossintáticas, foram o foco deste trabalho, que buscou evidenciar a forma como os futuros professores de E-LE percebem as diferenças pragmáticas codificadas em estruturas semelhantes entre as duas línguas, como no caso das Orações Condicionais, introduzidas pela conjunção Se. A interferência causada por essa grande semelhança vê-se agravada pela alta complexidade atribuída a essa estrutura, conforme afirmam diversos gramáticos e linguistas - Montolío, 1999; Moura Neves, 2000; Fernández Lanza, 2008.

Considerando toda a complexidade que envolve as orações condicionais e a problemática da formação de professores de espanhol no Brasil, este trabalho, a fim de responder ao questionamento que o motivou, desenvolveu testes, que contaram com três diferentes atividades, elaborados objetivando evidenciar a maneira como e se os sujeitos desta pesquisa, aprendizes e futuros professores de Espanhol, compreendem os efeitos de sentido que subjazem às construções Condicionais no Espanhol, ainda que estas sejam, estruturalmente, muito semelhantes às do Português.

A primeira atividade do teste pedia a reescrita de enunciados em Espanhol e elaboração de uma versão em Português, além das reflexões sobre seu processo de interpretação e produção. A análise confrontou as produções e as explicações fornecidas pelos sujeitos quanto aos elementos que contribuíram com ou dificultaram a elaboração dos enunciados, como conhecimentos linguísticos ou culturais. Nessa atividade, observou-se que os sujeitos declararam e demonstraram compreender plenamente a mensagem dos textos apresentados, inclusive quanto à percepção de possibilidade de realização denotada pelo uso do modo Indicativo que apresentavam. No entanto, ao produzir a versão em português adotaram o modo Subjuntivo. Essa escolha encontra explicação nas orações factuais que, segundo Perini (2010, p. 200), embora as gramáticas afirmem que o Indicativo é o modo da expressão de fatos, 0 "subjuntivo também aparece com a mesma característica" sendo necessário, porém, definir uma importante oposição semântica com relação à factualidade: quando é uma asserção - o falante exprime sua crença de que o que se segue é verdadeiro, emprega- 


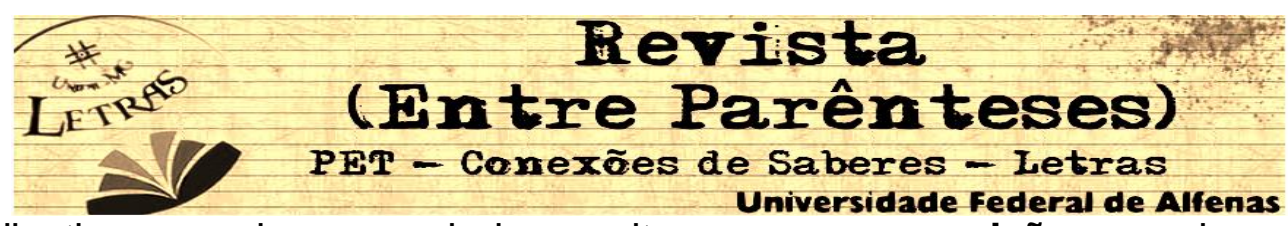

se o Indicativo; quando o enunciado permite uma pressuposição, ou seja, a verdade é inferida pelo receptor, o verbo fica no Subjuntivo.

Considerando que o enunciado original da tirinha (a) ¡Qué sabia es la naturaleza! Si ese pajarito caía muerto, yo no pegaba un ojo en tres meses. e do fragmento (b) El único consejo que les puedo dar es que lo abran y empiecen a leerlo. Si una vez empezado no les interesa, menos me van a creer a mí que a Cervantes exprimem a opinião do falante, de acordo com Perini (2010) o uso do Indicativo se justifica por constituírem uma asserção. O fato de os sujeitos terem utilizado o modo Subjuntivo em suas (re)construções pode encontrar apoio nesse mesmo princípio, considerando que as construções (a') Que boa é a natureza, se esse pássaro caísse morto, eu não fecharia os olhos por três meses e (b') Si começarem a ler e não se interessarem, vão acreditar menos em mim que em Cervantes, transmitem ao receptor uma certeza do falante permitindo a aquele pressupor que o pássaro não morreu em (a') e que a leitura de Cervantes será prazerosa em (b').

A segunda atividade apresentou conjuntos de enunciados em Espanhol semelhantes entre si quanto ao conteúdo, mas construídos com diferentes combinações modo-temporais. O objetivo foi verificar a percepção dos sujeitos sobre os efeitos de sentido consequentes dessas variações modo-temporais, especificamente quanto ao grau de possibilidade de realização das situações apresentadas. Observouse que este teste ofereceu maior dificuldade de execução aos sujeitos, conforme se notou na dispersão de respostas apresentadas. Ficou evidente que, quando se trata de ações realizáveis, marcadas pelo Indicativo, ou não realizáveis, denotadas pelo uso de Subjuntivo para os sujeitos, o grau de realização não gera dúvidas.

No entanto, as combinações modo-temporais que explicitam alguma eventualidade, propiciam maior desacordo, como no caso de a) Si lloviera, haríamos una buena cosecha ou b) ... si me tocaba la lotería, iba contigo. Moura Neves (2000) alerta para a possibilidade de realização denotada pelo [condicional] (futuro do pretérito, no Português) em (a), que para o falante de Português, permite considerar que futuro é o tempo de algo que é possível realizar. Ademais, a presença do [pretérito de subjuntivo] explicita o tempo passado, daquilo que não pode mudar, juntamente com o Subjuntivo, considerado o modo do improvável. Em (b) a dúvida é causada pelo uso do modo Revista (Entre Parênteses)

Volume 1, Número 5, 2016 - ISSN 2238-4502




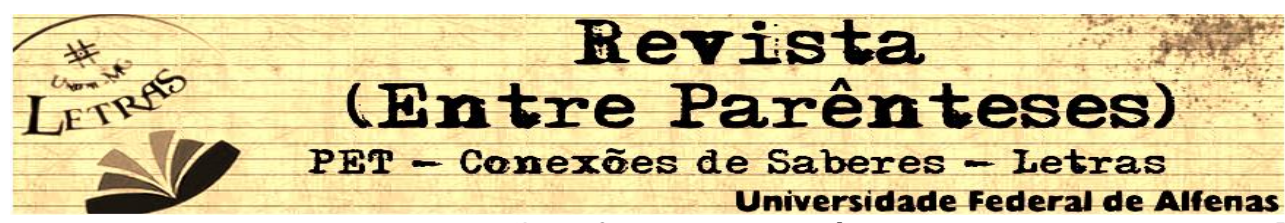

Indicativo, usual para explicitar ações factuais, porém, combinado com o [pretérito imperfeito], traz o sentido de algo possivelmente imutável, visto ser passado. Nesse caso, foi possível evidenciar que o efeito de sentido das orações condicionais apresentadas, ainda que para um enunciado em Espanhol, foi avaliado desde o conhecimento linguístico e pragmático que o sujeito tem do Português.

$\mathrm{Na}$ terceira atividade, os sujeitos tiveram que avaliar a probabilidade de realização de ações entre enunciados que apresentavam um mesmo contexto, desta vez expressos em Espanhol e sua correspondente versão em Português. Assim, criouse uma situação de confronto entre diferentes combinações modo-temporais para cada língua, solicitando dos sujeitos uma reflexão sobre como essas combinações afetam ou não o sentido explicitado no enunciado.

Os enunciados presentes no terceiro teste evidenciaram o efeito de sentido que o modo Indicativo denota para os falantes de Português. Em (a.1) Si llego a saberlo a tiempo lo impido, sabe-se que essa é uma situação sem possibilidade de realização ainda que construída com [presente de Indicativo] em ambas as orações, pois a perífrase verbal llegar + a, segundo Montolío (1999), denota impossibilidade de mudança. $O$ fato de metade dos sujeitos terem considerado provável sua realização corrobora com as conclusões de Moura Neves (2000) que afirma que, "no Português, o uso do Indicativo denota algo novo e com possibilidades de realização, enquanto que o Subjuntivo é utilizado frequentemente para as declarações contrafactuais”. Assim, o que parece ter norteado a percepção dos sujeitos foi a presença do Indicativo (saberlo) que "apagou" o efeito de sentido da perífrase verbal llegar $+a$.

A análise das produções dos sujeitos, tanto em Português quanto em Espanhol, como foi solicitado na primeira atividade, à luz das observações de Perini (2010) e Moura Neves (2000), evidencia que os sujeitos elaboram as produções com base nos conhecimentos linguísticos que têm do Português e nos seus conceitos pragmáticos, não percebendo claramente esses elementos nos enunciados em Espanhol.

$\mathrm{Na}$ segunda atividade, em que era necessário interpretar os enunciados, os sujeitos foram capazes de compreender o que declaravam, mesmo sendo iniciantes no curso, mas não perceberam claramente o subtexto, ou seja, compreendiam o sentido geral dos enunciados, mas não compreendiam elementos pragmáticos sutis Revista (Entre Parênteses) 


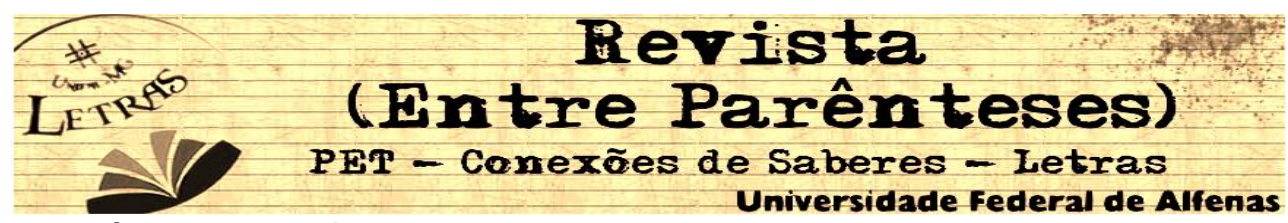

relacionados às construções modo-temporais dos verbos que apresentavam como no caso de si me toca la lotería, habría ido contigo em que metade dos sujeitos entendeu como realizável a ação por não perceberem que o passado (habría ido) apresenta uma situação imutável. Novamente, foi possível perceber que as respostas para o grau de factibilidade foram norteadas por parâmetros verbais próprios da língua materna. Esta foi a tarefa que apresentou maior dispersão por apresentar enunciados que parecem dizer a mesma coisa, desde que o sujeito não se atente para as variações nos efeitos de sentido que as combinações modo-temporais denotam, o que parece ter ocorrido.

A terceira atividade, ao confrontar enunciados em ambas as línguas, exigiu uma maior reflexão dos sujeitos e permitiu comprovar os sujeitos interpretam corretamente os enunciados, percebendo, inclusive, algum efeito de sentido, mas suas escolhas foram baseadas pensando a partir do Português.

Pode-se dizer que os sujeitos da pesquisa, independentemente do nível de estudos em Língua Espanhola, elaboraram interpretações semelhantes. Cabe ressaltar que entre os sujeitos encontram-se alunos iniciantes no estudo do Espanhol, incluídos nos $80 \%$ de sujeitos que declararam participar ou ter participado de programas como PET-Letras e Pibid, dentre os quais há alunos que atuam como professores e que já completaram seu percurso formativo de Língua Espanhola no Curso de Letras. Ou seja, não é o maior ou menor nível de estudos do Espanhol que teve influência nas produções em Espanhol. No que se refere aos efeitos de sentido implícitos nas combinações modo-temporais e, com relação às versões em Português, é possível afirmar que há uma forma particular de este falante interpretar o efeito de sentido do Subjuntivo para expressar situações condicionais, como algo cristalizado do ponto de vista gramatical. Ficou evidente que, para os sujeitos, falantes nativos de Português, os aspectos pragmáticos e os efeitos de sentido, decorrentes das combinações modo-temporais das construções condicionais em Espanhol, são, em algumas situações, imperceptíveis.

Conclui-se que os efeitos de sentido, construídos a partir de determinadas combinações modo-temporais, constituem um recurso linguístico muito mais utilizado no Espanhol que no Português, ainda que o número de combinações elencadas por Moura Neves (2000) seja consideravelmente maior que as relatadas por Montolío (1999). Isso pode ser um fator importante a ser considerado no processo de ensino da 


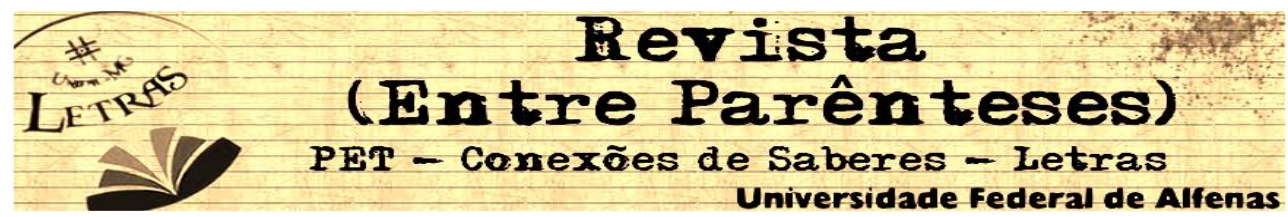

língua espanhola a falantes de português, já que pode interferir na compreensão que se tem da língua estrangeira e, em alguns casos, impossibilitar a comunicação.

Os resultados das análises desta pesquisa indicam que os sujeitos, futuros professores de E-LE, parecem não haver desenvolvido uma reflexão profunda sobre a aquisição da língua, como aponta Paiva (2005) quando questiona o pouco tempo dedicado à formação de professores nos cursos de Letras e a falta de uma formação voltada para o "pensar a língua", refletindo sobre o ensino e a aprendizagem da língua estrangeira. Ao desenvolver uma consciência linguística, é possível que esses sujeitos atentem para o fato de que, para desenvolver uma competência linguística de qualidade e, mais que isso, como futuros formadores, precisam ir além da capacidade de comunicar-se; que é preciso refletir sobre a língua que se pretende ensinar a fim de evitar a formação superficial apontada por Almeida Filho (1992, p. 78):

é urgente propormos, não uma solução, mas formas de ação que possam romper o ciclo vicioso em que se converteu o ensino neste país. O ciclo vicioso que se auto-abastece na formação insuficiente do professor na universidade, que engrossa a debilidade escolar do alunado e que por fim volta a alimentar a universidade precisa ser substituído por um ciclo virtuoso novo.

Mesmo mais de vinte anos depois, o chamado feito por Almeida Filho continua atual, pois ainda se observa que os cursos de Letras, com habilitação em Língua Estrangeira, seguem os mesmos modelos e apresentam as mesmas deficiências apontadas não só por ele, mas com base no referencial teórico consultado para este trabalho. A lacuna na formação dos futuros professores de E-LE evidenciada por esta pesquisa tem como fonte a crença de que a comunicação em uma LE consiste somente de um bom conhecimento gramatical, quando, na verdade, trata-se também de dominar um conjunto de recursos extragramaticais da mais alta complexidade, já que são o reflexo e a expressão da cultura do falante.

\section{Referências}

ALMEIDA FILHO, José Carlos P. O professor de Língua Estrangeira sabe a língua que ensina? A questão da instrumentalização lingüística. Contexturas, vol. 01, no 01, p. 7785, São Paulo: APLIESP, 1992 


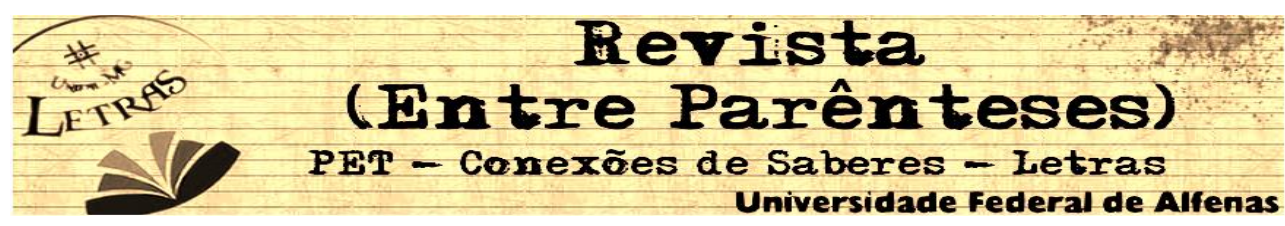

BRASIL. Secretaria de Educação Fundamental. Parâmetros curriculares nacionais: introdução aos parâmetros curriculares nacionais / Secretaria de Educação Fundamental. - Brasília : MEC/SEF, 1997.

BRUNO, Fátima A. T. C. Lo que uno/uma comprende, lo que uno/uma dice Compreensão e produção do espanhol como língua estrangeira por adultos brasileiros em situação de ensino e aprendizagem. Tese de Doutorado, DL FFLCH/USP, 2006.

ESCANDELL VIDAL, Mำ Victoria. Los fenômenos de interferência pragmática. MarcoELE: Revista de Didáctica, n. 9, p.95-110, 2009. Disponível em: http://marcoele.com/descargas/expolingua1996 escandell.pdf. Acesso em: 16/05/2014.

FERNÁNDEZ LANZA, Santiago. Una propuesta metodológica para la evaluación de condicionales. Revista de Filosofía, n. 2, vol. 33, p. 67-86, 2008.

FERNÁNDEZ LÓPEZ, Sonsoles. Interlengua y análisis de errores en el aprendizaje del español como lengua extranjera. Madrid: Edelsa Grupo Didascalia, S.A., 1997.

KULILOWSKI, Mํa Zulma \& GONZÁLEZ, Neide T.M. Español para brasileños. Sobre por dónde determinar la justa medida de una cercania. Anuario brasileño de estudios hispánicos, n. 9, p. 11-19, 1999.

MATTE BON, Francisco. Gramática Comunicativa del español: de la idea a la lengua - tomo II. 2.ed. 13.reimpr. España:EDELSA Grupo Didascalia, 1995.

MIZUKAMI, Ma da Graça N. Aprendizagem da docência: algumas contribuições de L. S. Shulman. Revista do Centro de Educação da UFSM. v. 29, n.02, 2004.

MONTOLÍO, Estrella. Las construcciones condicionales. In: BOSQUE, Ignacio. y DEMONTE, Violeta. (org). Gramática Descriptiva de la Lengua Española - entre la oración y el discurso/morfología. Madrid: Espasa Calpe S.A., 1999, p.3643.

MOURA NEVES, Mª Helena de. Gramática de usos do Português. São Paulo: Editora UNESP, 2000.

ORTEGA, Carlos de P. La enseñanza de aspectos sociopragmáticos en el aula de ELE. Actas del XVI Congreso Internacional de ASELE. Oviedo, España, 2005, p. 515-519. Disponível em: http://cvc.cervantes.es/ensenanza/biblioteca ele/asele/pdf/16/16 0513.pdf. Acesso em: 18/12/2014. 


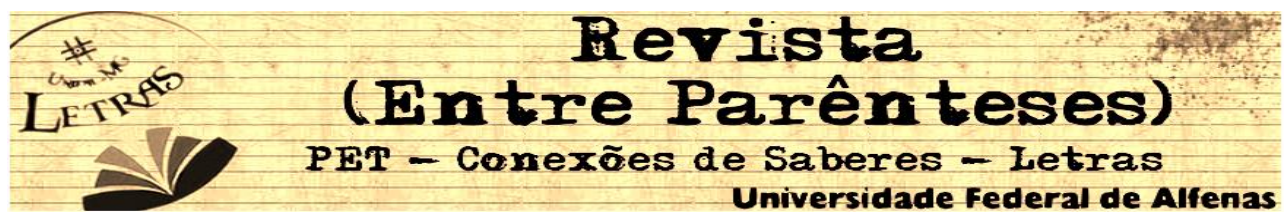

PAIVA, Vera Lucia M. O Novo Perfil dos Cursos de Licenciatura em Letras. In: TOMICH, L., et al (Orgs.). A interculturalidade no ensino de inglês. Florianópolis: UFSC, 2005. p.345-363 (Advanced Research English Series)

PERINI, Mario. Gramática do português brasileiro. São Paulo: Parábola Editorial, 1943-2010.

QUINO, Joaquín. Diez años com Mafalda. 23ª̊ed. Buenos Aires: Ediciones de la Flor, 2008, p. 147.

SANDES, Egisvanda I. A. O infinitivo flexionado no processo de aprendizagem do Espanhol como L2. Todas as Letras. n.3, p. 37-44, 2001.

VILLALBA, Terumi K. B. et al. Formación en Español: Iengua y cultura: dramatización: 9ํaño. Manual del profesor. Curitiba: Base Editorial, 2012, p.13.

VYGOTSKY, Lev. S. Pensamento e Linguagem. Tradução de Jefferson Luiz Camargo; revisão técnica José Cipolla Neto. 4.ed, São Paulo: Martins Fontes, 2008. 